\title{
Innovations in Equipping EYL Teachers for Future Challenges: UUM TEYL Perspective
}

\author{
Hamida Bee Bi Abdul Karim and Fahainis Mohd. Yusof \\ (Universiti Utara Malaysia, Sintok, Kedah, Malaysia) \\ doi:10.7575/aiac.alls.v.3n.2p.121
}

\begin{abstract}
This paper seeks to highlight perceptions of students undergoing the Teaching of English to Young Learners (TEYL) programme jointly run by UUM and KPM since 2004. It focuses on their level of satisfaction from both academic and non-academic aspects, particularly on the effectiveness of teaching methods employed by both local and international lecturers; use of up-to-date and 'world class' teaching materials and aids; and provision of first-hand experience of language teaching/learning situations both in local and overseas contexts. Students were also requested to highlight problems and constraints they encountered throughout the 4-year programme. Results generally indicated a high level of students' satisfaction. An interesting finding was the emphasis they placed on the need for and relevance of first-hand learning experience in real life classroom scenario.
\end{abstract}

\section{Introduction}

In the last few decades, Malaysia has stepped up its efforts in ensuring a high proficiency level in English among the students. This is in line with its rapid involvement in international business and trade. To achieve these visions, the Ministry of Education of Malaysia (MOEM) has also engaged in training future teachers of the nation as English teachers via several joint or twinning programmes with other institutions of higher learning - e.g. the Malaysia-United Kingdom B. Ed. Twinning Project (1992 - 2002) and the Bachelor of Education in Teaching English (TESL/TEYL) from 2002 - 2012. Basically, these joint or twinning programmes have, among other objectives, set the mission to "prepare effective, quality English language teachers for Malaysian schools" (Teacher Education Division, 2004).

\section{Background of the study}

On 16 June 2004, an educational collaborative agreement was signed between Universiti Utara Malaysia (UUM) and the MOEM whereby both parties have agreed to jointly run a 
coherent four-year pre-service teaching degree for the training of English language teachers for primary schools. This joint project is part of the nation's long term strategic socioeconomic plans under the New Economic Policy (DEB). It represents the MOEM's plan to upgrade Malaysian education in general, and ultimately improve the standard of English among all teachers in Malaysian schools. Hence, the project embarks on the mission of ensuring that quality education is made available to all Malaysians, both in the primary and secondary schools. The importance of English as a second language in the nation is also recognized via this project, whereby the main mission is to train teachers who are proficient in English and capable of contributing to the nation's development.

UUM was one of the local institutions of higher learning selected to participate in this newlydeveloped linking programme with MOEM. This degree programme was to be jointly developed, taught and monitored both by UUM and the then Maktab Perguruan Persekutuan Pulau Pinang (MPPPP), now known as Institut Pendidikan Guru Kampus Pulau Pinang (IPG). The running of the programme was in accordance with the agreed standards between both parties, whereby the degree will be conferred to successful candidates at the end of the programme by UUM. The programme structure to be adhered closely by both parties was known as the $1+2+1$ Model, preceded by a 2-year Foundation Course to be administered at the IPG. The model represents the students' movement from IPG in Year 1, to UUM in Year 2 and Year 3, and finally back to IPG in Year 4. However, students will have to attend the convocation for conferment of their degrees in UUM.

\section{Statement of the problem}

The first cohort of students under the link programme between UUM and MOEM, known as the Bachelor of Education in Teaching English to Young Learners (B.Ed. TEYL (Hons,), was registered officially as UUM students in the academic year 2002/2003. This was followed by four more cohorts, the last of which enrolled into UUM for the 2008/2009 academic session. Currently, the first cohort of students is awaiting their posting from the Division of Teacher Education, MOEM after completing their four-year programme at the end of the 2007/2008 academic session.

The likelihood of students facing problems may exist since this programme is run on a $1+2$ + 1 Model. As such, the TEYL students are faced with two different sets of learning environment, teaching personnel and teaching-learning facilities. There may also be 
limitations and shortcomings in the administration of the programme by the two separate institutions (academically and non-academically), which may eventually pose as a hindrance to students' overall performance in the programme.

However, to date, no studies have been conducted to determine the success (or failure) of the B.Ed. TEYL programme. On a more specific note, no studies have been conducted to look into issues or problems faced by students, be it during their stay in UUM or IPG. Therefore, there is a dire need for such a study such as this, mainly to probe into issues/problems faced by the TEYL students so that remedial steps can be taken to improve the programme for the benefit of the junior cohorts and future joint programmes.

\section{Objectives of the study}

The general objective of this study is to survey on the students' satisfaction of the B. Ed.TEYL programme, a link programme between UUM and MOEM. The specific objectives of this study are:

1. To establish whether the students are satisfied with the B. Ed. TEYL programme.

2. To ascertain the students' satisfaction of the joint programme from the academic perspective.

3. To highlight the problems/constraints encountered by the students and suggest ways to overcome them.

4. To recommend appropriate steps to improve existing and future joint programmes.

\section{Research questions}

Based on the objectives of the study, the following are the research questions:

Are the students satisfied with the B. Ed. TEYL programme?

1. Are the students satisfied with the academic aspects of the programme?

2. What are the problems encountered by the students during of the programme?

3. What are the suggestions needed to improve the joint programme?

\section{Significance of the study}

This study sets to obtain the TEYL students' general perspectives of the B. Ed. TEYL programme, which is a joint project between UUM and MOEM. Since this is the first time the programme is offered, the information gathered from this study will serve as invaluable input 
to the two institutions running it, i.e. UUM and IPG. The findings of this study will guide the authorities and administrators concerned on which areas/services to improve or modify to ensure the smooth running of the programme in the semesters to come, e.g. the bus service, teaching-learning facilities, counselling services, hostel facilities etc.

The study will also serve as a review to all the lecturers teaching the courses offered in the programme, especially with regards to the aims, topics and sub-topics, teaching-learning methods/approaches employed, teaching-learning materials used in the classrooms, the assignments and evaluation conducted etc. All the information gathered will assist them in improving the administration of the courses, particularly those concerning academic matters. The findings of this study will also hopefully benefit the students, particularly the junior cohorts. Awareness of existing problems and what should be done to improve the services and facilities provided on the part of the authorities and lecturers concerned will benefit the students both directly and indirectly.

Finally, the data gathered in this study will serve as a useful guide to the authorities concerned, particularly the BPG, in its future dealings or when considering new joint or twinning programmes with other institutions of higher learning.

\section{Limitations of the study}

Due to limitations in time and resources, this study only looks into issues from the students' perspectives. Due to similar constraints, this study concentrated only on one out of so many other joint programmes that MOEM has engaged in with other institutions throughout the nation.

Only B. Ed. TEYL programme students from Cohorts 1, 2 and 3 were used as the population in this study because the other two cohorts have not pursued their studies in UUM at the time this study was conducted. Hence, they were not able to express their views regarding issues related to UUM.

\section{Literature review}

This section reviews the empirical research literature relating to the students' satisfaction with their programme. The first part provides definitions of key terms. The remaining parts provide a brief overview of the theoretical underpinnings of each research area mentioned 
above and reviews the empirical studies that have been undertaken to date in each area. The probe into students' satisfaction with their course of study is an important research area within educational evaluation. With the growing concern for accountability in educational outcomes, the need for meaningful and stable measures has grown in importance.

\section{Definition of key terms}

\section{Satisfaction}

It is defined as being a consequence of the expectations and experiences of the subject and/or course (Banwet \& Datta, 2003).

\section{Joint programmes}

They refer to the engagement of two institutions in training future English teachers of the nation, with the mission of preparing effective, quality English language teachers for Malaysian schools (Teacher Education Division, 2004).

\section{Introduction}

Students' opinions about all aspects of academic life are now sought by educational institutions worldwide, generally, in the form of a satisfaction feedback questionnaire. It is this student satisfaction survey, within the context of Educational Studies, College of Arts and Sciences, Universiti Utara Malaysia that this paper addresses.

In relation to the international context, for instance, in the United Kingdom (UK), Higher Education (HE) students were considered to be the "primary customers" of a University (Crawford, 1991), even before they were liable for the payment of "up-front" tuition fees. Students are the direct recipients of the service provided, i.e. a three year degree programme, made up of a number of modules at each level. As if to confirm this status of the "student as customer", the Higher Education Funding Council for England (HEFCE) has introduced a National Student Survey. This survey is aimed at final year students to seek their views on a number of aspects of teaching, assessment and support provided by their university and its courses (HEFCE, 2003). The results will ultimately be used by Government and Funding Bodies to produce league tables of university performance. The position of a university in any league table will impact ultimately on its image. Image has a strong impact on the retention of current students and the attraction of potential students (James, Baldwin \& McInnis, 1999). 
Indeed, recruitment and retention of students has been moved to the top of most universities' agendas by HEFCE due to their desire to increase the UK student population in line with the Government targets. Poor retention rates may have adverse funding consequences for institutions (Rowley, 2003a). This paper takes the view that student satisfaction, retention and recruitment are closely linked. Thus student satisfaction has become an extremely important issue for universities and their management. The aim is to try to maximize student satisfaction, minimize dissatisfaction and therefore retain students and to improve the institution's performance across Joint Programmes in Malaysia.

A number of previous research studies (Galloway, 1998; Banwet \& Datta, 2003) into student perceptions of quality/satisfaction have utilised the SERVQUAL framework (Parasuraman, Zeithaml, \& Berry, 1988). However, SERVQUAL has been much criticized over the years (Buttle, 1996; Asubonteng, McCleary \& Swan, 1996; Pariseau \& Mc Daniel, 1997; Idridge \& Rowley, 1998). Taking these criticisms into consideration, the questionnaire used in the satisfaction survey asked only for perceptions of performance of a range of service aspects (as well as importance), but did not aim to collect data associated with expectations. Indeed, the survey questionnaire was designed around the concept of the service-product bundle. This concept is discussed in the next section.

\section{Teacher education philosophy and its implications for the roles of teachers}

Based on the spirit of the National Education Philosophy, the Teacher Education Philosophy will determine the course of direction and source of inspiration for teachers to follow as well as to excel in the teaching profession. It states:

Teachers with noble characters, progressive and scientific outlook would be prepared to uphold the nation's aspiration as well as to exalt the nation's inherited culture, to ensure individual development and to safeguard a united, democratic, progressive and disciplined society (Teacher Education Division, 2003).

\section{Objectives of teacher education}

With regard to the Teacher Education Philosophy stated above, the main objective of teacher education is to train and produce teachers with good personal, professional, social and moral qualities. Teachers are to acquire knowledge, teaching skills and practice moral 
values that conform to the teaching profession as well as to fulfil the aims and aspirations of the Education Vision programmes for the 21 st century.

\section{Issues impacting on student satisfaction}

Price, Matzdorf, Smith and Agahi (2003) reported on the impact of facilities on undergraduate students' choice of university. They surveyed a number of universities over two years in order to determine students' reasons for selecting a particular university. The average results for the two years were fairly similar - the top eight reasons being; it offers the right courses, the availability of computers, the high quality of library facilities, good teaching reputation of lecturers, availability of "quiet" areas, the availability of areas for self-study, the quality of public transport in the town/city and a friendly attitude towards students. Clearly, students' perceptions of a university's facilities are one of the main influences on their decision to enrol into a particular programme offered by the institution.

Coles (2002) found that student satisfaction decreases when class sizes were larger in earlier cohorts, and also when students are taking compulsory core modules rather than optional modules. The quality of any of the service counters, or "moments of truth" (Carlzon, 1989) experienced by customers forms part of their overall impression of the whole service provided, (Dale, 2003) and by implication, their impression of the organisation itself.

As Deming (1982) commented, most people will form their opinions based on the people that they see, and they are either dissatisfied or delighted, or at some other point on the continuum in between. In order to deliver high quality services to students, universities must manage every aspect of the student's interaction with all of their service offerings and in particular those involving people or customers. Services are delivered to people by people, and the moments of truth can make or break a university's image (Banwet \& Datta, 2003). In order to deliver total student satisfaction, all employees of a university should adhere to the principles of quality customer service, whether they be front-line contact staff involved in teaching or administration, or non-contact staff in management or administrative roles (Gold, 2001; Low, 2000).

Banwet and Datta (2003) believed that satisfied customers are loyal. Parallel to that, satisfied students were likely to attend another lecture delivered by the same lecturer or opt for another module or course taught by her/him. In their survey of 168 students who 
attended four lectures delivered by the same lecturer, covering perceived service quality, importance and post-visit intentions, they found that students placed more importance on the outcome of the lecture (knowledge and skills gained, availability of class notes and reading materials coverage and depth of the lecture and teacher's feedback on assessed work) than any other dimension. This supports the findings of Schneider and Bowen (1995) who deduced that the quality of the core service influences the overall quality of the service perception. For universities, the core service delivery method employed by lecturers is still the lecture method. Overall, Banwet and Datta (2003) found that students' intentions to reattend or recommend lectures was dependent on their perceptions of quality and the satisfaction they got from attending previous lectures. This is supported by the research of Hill, Lomas and MacGregor (2003) who utilised focus groups to determine what quality education meant to students. The most important theme was the quality of the lecturer including classroom delivery, feedback to students during the session and on assignments, and the relationship with students in the classroom.

Research by Tam (2002) to measure the impact of Higher Education (HE) on student's academic, social and personal growth at a Hong Kong university found that as a result of their university experience, students had changed intellectually, socially, emotionally and culturally. This growth was evidenced as students progressed from one year to another as their university career developed. Is this also the case with student's perceptions of service quality and satisfaction? A number of researchers have suggested that this might indeed be the case (Hill, 1995; O'Neil, 2003) although obtaining valid and reliable data to support such a stance is difficult. This study aims to determine if there are differences in those aspects of academic and non- academic in both institutions that students consider important, as well as their satisfaction levels, associated with their year/level of study, i.e. first, second and third cohorts.

In a recent survey conducted with 310 all male Saudi Arabian students attending the King Fahd University of Petroleum and Minerals, Sohail and Shaikh (2004) found that "contact personnel" was the most influencing factor in student's evaluation of service quality. However, physical environment, layout, lighting, classrooms, appearance of buildings and grounds and the overall cleanliness also significantly contributed to students' concepts of service quality. 
Why collect student feedback?

Rowley (2003b) identified four main reasons for collecting student feedback:

- to provide auditable evidence that students have had the opportunity to pass comments on their courses and that such information is used to bring about improvements;

- to encourage student reflection on their learning;

- to allow institutions to benchmark and to provide indicators that will contribute to the reputation of the university in the marketplace; and

- to provide students with an opportunity to express their level of satisfaction with their academic experience.

The last bullet point is the rationale behind the survey undertaken for the particular research project described in this paper.

\section{The service-product bundle}

The outcome of service delivery is a tangible product, and a "bundle" of goods and services as the product offering (Sasser, 1995). The service-product bundle refers to the inseparable offering of many goods and service including what the Educational Studies, College of Arts and Sciences, Universiti Utara Malaysia has to offer its students. This bundle consists of three elements:

1. the physical or facilitating goods;

2. the sensual service provided - the explicit service; and

3. the psychological service - the implicit service.

For a university, the facilitating goods include the lectures and tutorials, presentation slides, supplementary handout documents/materials and the recommended module texts. It also includes the physical facilities such as the lecture theatres and tutorial rooms and their residential colleges and hostels as well as ancillary services such as co-curricular, counselling, support and mentoring system.

The explicit service includes the knowledge levels of staff, staff teaching ability, the consistency of teaching quality irrespective of personnel, ease of making appointments with staff, the level of difficulty of the subject content and the workload. 
The implicit service includes the treatment of students by staff, including friendliness and approachability, concern shown if the student has a problem, respect for students' feelings and opinions, availability of staff, capability and competence of staff. It also includes the ability of the university's environment to make the student feel comfortable, the sense of competence, confidence and professionalism conveyed by the ambience in lectures and tutorials, feelings that the student's best interest is being served and a feeling that rewards are consistent with the effort put into course works/examinations. All of the above are based on students' perceptions of the various parts of the service and the data is usually collected via some form of feedback questionnaire.

\section{Methods}

A survey method was adopted in this study. It was an adaptation of Entwistle, Mc Cune \& Hounsells' (2002) The Experiences of Teaching and Learning Questionnaire (ETLQ). The survey comprised 6 items on demographic details, 29 items on academic aspects and 13 items on non-academic aspects for both institutions in which the Likert scale inventory was used. The concept of the service-product bundle was adapted to design the survey questionnaire. For the purpose of this paper, only findings from the academic aspects are focused. The questionnaire was pilot tested and a Cronbach's Alpha of 0.967 (high reliability) was achieved. However, some minor amendments were made to a few items in the questionnaire. A total of 150 students were involved as the sample of this study were 74 pre-service teachers from Cohort 1, 72 teachers from Cohort 2 and 75 from Cohort 3 of the B.Ed. TEYL

programme - they were in their 8 th semester, $6^{\text {th }}$ and $4^{\text {th }}$ semesters at time of data collection. The data analysis was carried out using quantitative method and presented in terms of percentages. The written responses obtained from the open-ended questions, served the purpose of triangulating the reliability of the data.

\section{Findings and discussions}

$R Q$ 1: Student Satisfaction of the B. Ed. TEYL programme

A total of 95 percent of the respondents were satisfied with the programme because the aims of the courses are achievable. This indicates that students feel this programme had updated their knowledge and exposed them to innovations in the KBSR English syllabus. 
Table 1: Student satisfaction of the programme

\begin{tabular}{ccc}
\hline \multicolumn{1}{c}{ Academic } & UUM & IPGM \\
\hline $\begin{array}{l}\text { 1. Generally satisfied with the } \\
\text { programme }\end{array}$ & $95 \%$ & $94 \%$ \\
\hline
\end{tabular}

$R Q$ 2: Satisfaction with the academic aspects of the programme

a) A majority of respondents agreed that the courses are helpful in assisting them to teach English to young learners successfully. The programme succeeded in helping teachers in their career as well as enabled them to grasp innovation in the curriculum.

Table 2: Student satisfaction of academic aspects

\begin{tabular}{lcc}
\hline \multicolumn{1}{c}{ Academic } & UUM & IPGM \\
\hline $\begin{array}{l}\text { 8. The course handouts/materials } \\
\text { given were very helpful }\end{array}$ & $89.2 \%$ & $85.2 \%$ \\
$\begin{array}{l}\text { 9. The learning experiences } \\
\text { encouraged me to rethink my }\end{array}$ & $91.9 \%$ & $90.5 \%$ \\
$\begin{array}{l}\text { understanding of the courses } \\
\begin{array}{l}\text { 16. The instructor share their } \\
\text { knowledge and experience about } \\
\text { the content of the courses and } \\
\text { innovations with students }\end{array}\end{array}$ & $86.5 \%$ & $86.5 \%$ \\
\hline
\end{tabular}

b) A majority felt that the courses motivate them to engage in their professions. The exposure and familiarity of the KBSR English syllabus in the courses were indeed a help to them in classroom teaching.

Table 3: Student satisfaction of KBSR syllabus

\begin{tabular}{|c|c|c|}
\hline Academic & UUM & IPGM \\
\hline $\begin{array}{l}\text { 24. We are encouraged to think critically } \\
\text { and creatively in the courses }\end{array}$ & $90.5 \%$ & $93.2 \%$ \\
\hline $\begin{array}{l}\text { 25. The current topics help me to make } \\
\text { connections to my existing knowledge and } \\
\text { experiences }\end{array}$ & $91.9 \%$ & $91.9 \%$ \\
\hline $\begin{array}{l}26 . \text { We are encouraged to think about how } \\
\text { best to tackle the set work }\end{array}$ & $87.9 \%$ & $87.9 \%$ \\
\hline
\end{tabular}

c) However, about 30 percent of the respondents showed their dissatisfaction with the arrangement/organization of topics and subtopics of the courses. Here, the respondents seemed to expect more well-organized and logical flow of topics and sub-topics of each course. 
Table 4: Student dissatisfaction of the organization of topics

\begin{tabular}{|c|c|c|}
\hline Academic & UUM & IPGM \\
\hline $\begin{array}{l}\text { 2. The topics of the courses are } \\
\text { arranged in a logical/ sensible } \\
\text { way }\end{array}$ & $29.7 \%$ & $20.3 \%$ \\
\hline $\begin{array}{l}\text { 3. The subtopics of the course } \\
\text { units are well-organised }\end{array}$ & $25.7 \%$ & $21.6 \%$ \\
\hline
\end{tabular}

$R Q$ 3: Problems/constraints encountered by the students during the course of the programme This part of the survey required students to express their views and opinions through their written responses. Amongst the problems or issues highlighted by the respondents were:

Top on the list was the duration of the programme which according to the respondents was too long. This is because before undergoing the 4-year first degree programme, they had to do a 2-year foundation English programme. The respondents also expressed their dissatisfaction with the lack of teaching and learning facilities. A majority of the respondents also expressed their dissatisfaction with what they termed as "some redundancy or overlapping in the course contents".

The next issue raised was the claim that there were too many assignments for many of the courses offered in both organisations. An interesting finding was the respondents' comment that there was no feedback given on the assignments by some lecturers. Finally, some of the students were not satisfied with the structure of the joint programme, which was basically the $1+2+1$. This structure requires them to study in the IPGM in Year 1 and, whilst in Year 2 and 3 they have to attend classes and stay in UUM.

\section{RQ4: Students' suggestions on how to improve the B. Ed. TEYL programme}

The students proposed several interesting suggestions to improve or make the programme more interesting and practical in future. It should be mentioned at this point that some of their suggestions have actually been taken up and carried out while students were both in UUM and IPGM.

One of them is task-based learning or school-based learning activities conducted during visits to selected primary schools throughout Malaysia, both in urban as well as rural areas. These activities are usually one-day events conducted towards the end of the semester or during the 
semester break. Here, students carry out activities and games which they have learned from the courses they had taken in the programme, e.g. ELT Methodology, ELT Curriculum Studies, Teaching Reading and Writing and Teaching Aural-Oral Skills.

During their visits to schools, students would facilitate Year 1 to Year 6 primary school pupils with various activities such as language games, songs, role-plays, simulations, journal writing and the 'Big Book'. These activities would benefit both the school pupils and the B. Ed. TEYL students. The former would get to use English in real-life situations, while the latter would be exposed to natural authentic contexts - something like micro-teaching situations - with real students. Among the objectives of these task-based activities are to create opportunities to link theory into practice, expose them to real classroom contexts, and experience both rural and urban environments which pose as useful pre-posting orientation for the students.

The second of such activities suggested by students and carried out with the help of authorities concerned were what were termed as 'research-driven activities'. The first of such activities was the educational trip to Perth, Australia. Twenty-three Cohorts 3 and 4 students went on the trip and visited the Edith Cowan University (ECU) and Hollywood Primary School. Amongst the benefits of the trip were the first-hand experience students got of western learning culture and foreign classroom contexts. Besides, the students also became 'real researchers when they were required to do reflective thinking of the benefits of the trip to them. In fact, some of them highlighted several interesting possible research areas or topics in their reports. Among them are Sociolinguistics Knowledge (Australian accent), Literacy Development, Communicative Language Teaching, English as an International Language (EIL), Culture and Policy, and Speaking and Listening.

Finally, the students suggested some possible activities as a follow-up to the Australian trip. Among them are opening up opportunities for them to continue their studies at the ECU or other Australian universities, organizing exchange programmes for Malaysian TEYL students to study in Australia (a cross-cultural TEYL programme), and engaging in teaching practicum exchange programme in collaboration with foreign universities. 


\section{Conclusions}

In conclusion, despite the limited scope of the study, the results as well as the entire process reported in this paper seem to indicate that the main objective of the study was successfully achieved; and that the majority of the students were satisfied with the aims of the courses offered by both institutions. On the other hand, students were dissatisfied with the organisation/arrangement of the topics and sub-topics of the courses. Given that organisation/arrangement of the topics and subtopics is vital for the programme, it can be said that lecturers take their time to put more emphasis on theoretical aspects rather than practical aspects in the courses. Finally, the limited use of teaching modes by lecturers from both institutions is yet another factor against this dissatisfaction

\section{Recommendations}

The present study has raised a number of recommendations that may merit further attention, four of which will be listed here:

1. Joint Programmes should have clear and well-stated aims and objectives in line with the Malaysian Qualifications Framework (MQF) requirement.

2. The structure of the joint programmes should be more systematically organized.

3. Joint programmes should offer more courses using methodological syllabuses, (more on the "how" of teaching).

4. Lecturers should expose students to more school-based experience and provide them with authentic classroom materials (video, journal articles etc)

\section{Implications}

The study seems to suggest several positive implications for the programme. Firstly, is that the aims of the programme are achievable in both institutions because they were clearly stated. Next, the course contents should be presented in a logical and well-sequenced manner. As students take their learning seriously and pay attention to the organisation of the content of the courses offered, they prefer the 'how to' rather than the 'what of' teaching. Furthermore, lecturers should be more innovative and creative in their teaching. 


\section{References}

Asubonteng, P., McCleary, K.J., Swan, J.E. (1996). SERVQUAL revisited: A critical review of service quality. The Journal of Services Marketing, Vol. 10 No.6, pp.62-81.

Banwet, D.K., Datta, B. (2003). A study of the effect of perceived lecture quality on post-lecture intentions. Work Study, Vol. 52 No.5, pp.234-43.

Buttle, F. (1996), SERVQUAL: review, critique, research agenda. European Journal of Marketing, Vol. 30 No.1, pp.8-32.

Carlzon, J. (1989). Moments of truth. New York: HarperCollins.

Coles, C. (2002). Variability of student ratings of accounting teaching: evidence from a Scottish business school. International Journal of Management Education, Vol. 2 No.2, pp.30-9.

Crawford, F. (1991). Total Quality Management, Committee of Vice-Chancellors and Principals, occasional paper (London, December), cited in Hill, F.M. (1995), Managing service quality in higher education: the role of the student as primary consumer. Quality Assurance in Education, Vol. 3 No. 3, pp. 10-21.

Dale, B.G. (2003). Managing Quality. 4th ed. Oxford: Blackwell Publishing.

Deming, W.E. (1982). Out of the Crisis. Cambridge: Massachusetts Institute of Technology.

Entwistle, N.J., Mc Cune, V \& Hounsell, D. (2002). The Performance of Electrical Engineering Students in Scottish Higher Education. Edinburgh: University of Edinburgh,

Centre for Research on Learning and Instruction.

Galloway, L. (1998). Quality perceptions of internal and external customers: a case study in educational administration. The TQM Magazine, Vol. 10 No.1, pp.20-6.

Gold, E. (2001). Customer service: A key unifying force for today's Campus, Netresults, National Association of Student Personnel Administrators. 22 January. Retrieved from: www.naspa.org/netresults, cited in Banwet, D.K. and Datta, B. (2003). A study of the effect of perceived lecture quality on post-lecture intentions. Work Study. Vol. 52 No 5, pp. 234-43.

HEFCE, UUK and SCP (2003). Final report of the TQEC on the future needs and support for quality enhancement of learning and teaching in higher education. London: TQEC.

Hill, F.M. (1995). Managing service quality in higher education: the role of the student as primary consumer. Quality Assurance in Education, Vol. 3 No.3, pp.10-21.

Hill, Y., Lomas, L., MacGregor, J. (2003). Students' perceptions of quality in higher education. Quality Assurance in Education, Vol. 11 No.1, pp.15-20.

ldridge, S., Rowley, J. (1998). Measuring customer satisfaction in higher education. Quality Assurance in Education, Vol. 6 No.4, pp.197-204.

James, D.L., Baldwin, G., McInnis, C. (1999). Which University? the factors influencing the choices of prospective undergraduates. Melbourne: Centre for the Study of Higher Education.

Low, L. (2000). Are college students satisfied? a national analysis of changing expectations, Noel-Levitz, Iowa City, IA, cited in Banwet, D.K. and Datta, B. (2003). Study of the effect of perceived lecture quality on post-lecture intentions. Work Study, Vol 52 No 5, pp. 234-43.

O'Neill, M. (2003). The influence of time on student perceptions of service quality: the need for longitudinal measures. Journal of Educational Administration, Vol. 41 No.3, pp.310-24.

Parasuraman, A., Zeithaml, V.A., Berry, L.L. (1988). SERVQUAL: a multiple-item scale for measuring conumer perceptions of service quality. Journal of Retailing, Vol. 64 No.1, pp.12-24.

Pariseau, S.E., McDaniel, J.R. (1997). Assessing service quality in business schools. International Journal of Quality and Reliability Management, Vol. 14 No.3, pp.204-18.

Price, I., Matzdorf, F., Smith, L., Agahi, H. (2003). The impact of facilities on student choice of university. Facilities, Vol. 21 No.10, pp.212-22.

Rowley, J. (2003a). Retention: rhetoric or realistic agendas for the future of higher education. The International Journal of Educational Management, Vol. 17 No.6, pp.248-53.

Rowley, J. (2003b). Designing student feedback questionnaires. Quality Assurance in Education, Vol. 11 No.3, pp.142-9.

Sasser, W.E. Jr (1995). Why satisfied customers defect. Harvard Business Review, November-December, pp.8899.

Schneider, B., Bowen, D.E. (1995). Winning the Service Game. Boston, MA: Harvard Business School Press.

Sohail, M.S., Shaikh, N.M. (2004). Quest for excellence in business education: a study of student impressions of service quality. The International Journal of Educational Management, Vol. 18 No.1, pp.58-65.

Tam, M. (2002). Measuring the effect of higher education on university students. Quality Assurance in Education, Vol. 10 No.4, pp.223-8.

Teacher Education Division. (2004). Ministry of Education. Perjanjian Kerjasama Pendidikan bagi Program Kembar Praperkhidmatan B. Ed. (TESL) antara Kerajaan Malaysia dengan Universiti Utara Malaysia $2002-2011$. 